Canadian University Music Review

Revue de musique des universités canadiennes

\title{
An Assessment of the Organ Miniatures of Healey Willan
}

\section{Peter Hardwick}

Numéro 1, 1980

URI : https://id.erudit.org/iderudit/1013732ar

DOI : https://doi.org/10.7202/1013732ar

Aller au sommaire du numéro

Éditeur(s)

Canadian University Music Society / Société de musique des universités

canadiennes

ISSN

0710-0353 (imprimé)

2291-2436 (numérique)

Découvrir la revue

Citer cet article

Hardwick, P. (1980). An Assessment of the Organ Miniatures of Healey Willan. Canadian University Music Review / Revue de musique des universités

canadiennes, (1), 8-21. https://doi.org/10.7202/1013732ar

All Rights Reserved (C Canadian University Music Society / Société de musique des universités canadiennes, 1980
Ce document est protégé par la loi sur le droit d'auteur. L'utilisation des services d’Érudit (y compris la reproduction) est assujettie à sa politique d'utilisation que vous pouvez consulter en ligne.

https://apropos.erudit.org/fr/usagers/politique-dutilisation/ 


\title{
AN ASSESSMENT OF THE ORGAN MINIATURES OF HEALEY WILLAN*
}

\author{
Peter Hardwick
}

Born at Balham, Surrey, on 12 October 1880, James Healey Willan's lifelong association with the Anglican Church began with the musical education he received between 1889 and 1895 at St. Saviour's Choir School, Eastbourne, under the influence of the choirmaster and organist Walter Hay Sangster. When the Willan family moved to St. Albans, a city twenty miles north of London, the young Willan commuted to the metropolis once a week to continue his education in church music under William Stevenson Hoyte, organist at All Saints', Margaret Street. An Associate of the Royal College of Organists (ARCO) by 1896, Willan passed the Fellowship examination of the College (FRCO) in 1899.

By now Willan had embarked upon what might be called the English phase of his career as a church organist: St. Saviour's, St. Albans (1897-1900); Christ Church, Wanstead, London (1900-03); and St. John the Baptist, Holland Park, London (1903-13). During his time at St. John the Baptist he gained a reputation as an authority on plainsong in English and had several of his organ works published by Novello.

In 1913 Willan emigrated to Canada to become head of the Toronto Conservatory's Theory Department. Shortly after arriving in this country he accepted the position of organist and choirmaster at the new St. Paul's Church, Bloor Street, an enormous edifice opened for public worship in November 1913. In 1921 he became music director at St. Mary Magdalene, Manning Avenue, a position he held until his death forty-seven years later.

*This paper is a revised version of "Healey Willan's Organ Miniatures," The Musical Times, CXXI/1652 (October 1980), 651-54. Reprinted by permission. 
Among the published works for organ are six large recital pieces that lie beyond the scope of this paper: Prelude and Fugue in C Minor (1909), Epilogue (1909), Introduction, Passacaglia and Fugue (1919), Interlude for a Festival (1954), ${ }^{1}$ Epithalame (1957, subtitled Sortie), and Passacaglia and Fugue No. 2 in E Minor (1959). Not unexpectedly, Willan wrote shorter pieces for the organ, presumably for use as preludes, interludes, and postludes at church services. In this category are several longer works that might be considered recital pieces rather than functional miniatures. But by and large the works which appear in the appended catalogue are clearly miniatures, the titles of many of the pieces reflecting their assumed function, though all make suitable recital material.

The miniatures may be divided into two main categories according to whether or not they make use of pre-existent melodies; for convenience, we will label those using pre-existent sacred melodies with the generic term "chorale prelude," even though the majority of the hymn tunes are not Lutheran in origin.

\section{THE CHORALE PRELUDES}

In this category there are ninety-nine published works, almost all from 1950 or later. Most are in a traditional style and in forms derived from those found in the works of Bach, an indebtedness anticipated in the organ compositions of Willan's influential British forebears, C. Hubert H. Parry (1848-1918) in particular, and Charles Villiers Stanford (1852-1924). The same Brahmsian harmonic language is used by these two in their organ music, notably in Parry's Seven Chorale Preludes, Set I (1912) and Set II (1916), and in Stanford's Six Short Preludes and Postludes, Set I (Op. 101, 1907) and Set II (Op. 105, 1908). Many in the Parry collections point the way to Willan's chorale preludes - those, for example, on the hymn tunes "Rockingham" and "Martyrdom," which present the melodies, solo, in the soprano and tenor registers respectively, with soft undulating contrapuntal or pseudo-contrapuntal introductions, interludes, and codas - manners of presentation particularly favored by Willan in the post-1950 period.

Stanford appears to have shown little interest in sacred melodies as the foundation for his organ pieces; only two pieces in his Opp. 101 and 105 fall into this category (Op. 101, Nos. 5 and 6, both "on an old Irish church melody"). But Willan followed 
the interest in Tudor music seen in Stanford's quotations of Orlando Gibbons in Op. 105. Op. 105, No. 1 especially shows the pseudo-Tudor vocal-style counterpoint favored by Willan in his chorale preludes, with the gently rising and falling points of imitation weaving their web of sound over the Gibbons theme played on a soft reed stop on the pedals. Willan's organ miniatures, however, lack comparable breadth and variety: for instance, they contain nothing to match the technical demands of Parry's showpieces on the hymn tunes "Hanover," "St. Thomas," or "St. Ann's." Willan also wrote chorale preludes in the style of his English contemporary Percy W. Whitlock (190346), but several of Whitlock's Six Hymn-Preludes (two sets, 1945) demand far more of virtuosity than do Willan's.

Willan's texture is usually four-voice. The hymn melodies are mostly unembellished, and in sixty-three of the published chorale preludes the melody is presented in the soprano, with two lower parts in the left hand and one in the pedals. In twenty-two cases the pre-existent melody is placed in the tenor (left hand), with two parts in the treble (right hand) and one in the pedals. The other favored alignment is to have the melody in the pedals: twelve chorale preludes have the theme partially (4) or wholly (8) in the pedals. On seven occasions Willan uses canonic treatment of the melody, ${ }^{2}$ while only in "Aberystwyth" (Ten Hymn Preludes, Set I, No. 10) and "Slane" does he alternate the phrases between soprano and tenor.

The accompanying voices are divided about evenly between counterpoints derived from the hymn tune and free ones. Unlike the post-1950 works, early settings, such as that of "Puer nobis nascitur," are in a harmonically conceived contrapuntal style, and the metric accents are regular. Absent in these early pieces are the syncopations and imitative writing that were to become so familiar in the later compositions in this genre.

The clue as to the change in Willan's contrapuntal style may lie in a statement he once made on his style in general: "It is one of my faults that I have not kept up very well with today's musical developments. But for many years my free time, away from my lecturing, has been devoted to writing music for choirs. You might say I have been steeped in Tudor tradition" (Quoted in Bradley 1977: I, 4). Willan's interest in and use of Tudor features spilled over into his organ music in the post-1950 
period, with their imitations, suspensions, and essentially vocal idiom.

The other important influence on Willan's general church style was Gregorian chant. His knowledge of plainsong may be traced back to his earliest years, to visits to St. George's Church, Beckenham, Kent, where the services were AngloCatholic with plainsong in the vernacular being sung on a regular basis. His studies in the 1890s with William Hoyte, organist at All Saints', would have furthered his exposure to the Roman chants. ${ }^{3}$ As a young man, he became a friend and associate of Francis Burgess, the founder of the Gregorian Association in London. Finally, there were his forty-seven years at St. Mary Magdalene where plainsong chanting and hymn-singing in the vernacular were an integral part of the liturgy.

Willan's adoption of the flowing, eminently "singable" style of Gregorian chant is a basic element of much of his later counterpoint and melodic material. This impression is especially strong in the Five Preludes on Plainsong Melodies. In a foreward to this work he suggested that "In Nos. 2, 3, and 4 . . each line [ of the melody ] begin with a definite impulse, and a slight rallentando and diminuendo should be introduced toward the end of each line." The modality of the melodies, with their rhythmic flexibility, and the Latin texts accompanying the Gregorian hymn tunes provide clear indicators to the source of inspiration. Furthermore, in places the counterpoint may be said to capture the spirit of organum, though the improvisational nature of these passages with their parallel seventh chords may also suggest other more recent influences.

Despite the limitations inherent in working within modest technical limits, Willan nevertheless quite often turned his hand to creating chorale preludes in a different mold from these conventional types, often with very refreshing results. For example, the Sicilienne on "Capetown" (Ten Hymn Preludes, Set I, No. 4), the Partita on "St. Flavian" (Ten Hymn Preludes, Set I, No. 5), the Fughetta on "Iste confessor" (Ten Hymn Preludes, Set III, No. 3), and the Trio on "St. Venantius" (Ten Hymn Preludes, Set III, No. 9) may be described as romanticized enterprises in neo-Baroque writing.

Willan's setting of Martin Luther's contrafactum, "Christum wir sollen loben schon," based on the ancient plainsong in the Phrygian mode, A solis ortus cardine, is perhaps unique in organ literature in Willan's use of the original plainsong with its 
rhythmic freedom for the interludes between the phrases of the chorale, while the chorale itself is in the style of the sixteenthcentury Lutheran composers. Also unique among Willan's miniatures is his setting of the first stanza of the Lutheran hymn for the burial of Christ, "O Traurigkeit" (Six Chorale Preludes, Set II, No. 2), where he writes in the harmonic style of Brahms, Wagner, and Reger, a style he favored in much of his other music but appears to have considered generally unsuitable for the organ. Much of the sense of anguish in the hymn text is transported into the musical texture by suspensions which create, for example, eleventh chords (mm. 4, 5, \& 23) and diminished seventh chords (mm. 18, 20, 21, \& 30). But the chromatic part-writing is perhaps even more noteworthy and unusual. Cross-relations occur several times, twice simultaneously, and augmented intervals, melodic and harmonic, arise from other chromatic part-writing. In measures 16,17 , and 27 these strivings after extreme pathos result in chord alignments almost impossible to play (Ex. 1):4

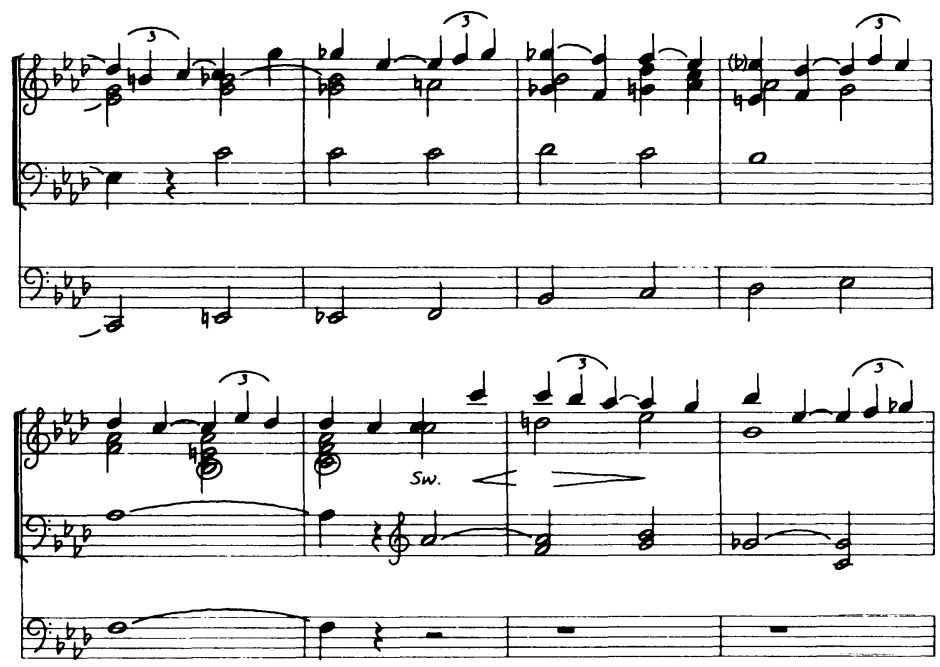

Copyright $\odot 1951$ by Concordia Publishing House. Reprinted by permission.

Example 1. Willan: Chorale Prelude on "O Traurigkeit"

(Six Chorale Preludes, Set II, No. 2), mm. 12-19.

The setting of "Ave maris stella" (Five Preludes on Plainsong Melodies, No. 4) contains an oscillating, wave-like eighth-note moto perpetuo suggesting the movements of the sea described 
in the hymn's first line - a rare instance of Willan's sketching in literal musical terms.

Most of the more energetic, more brilliant, louder pieces built on hymn tunes have striking openings and conclusions that smack of Willan the highly gifted improviser. Of these, none is more daring harmonically than the opening of the prelude on "Vexilla regis" (Six Chorale Preludes, Set II, No. 6), which opens with the first four notes of the plainsong theme
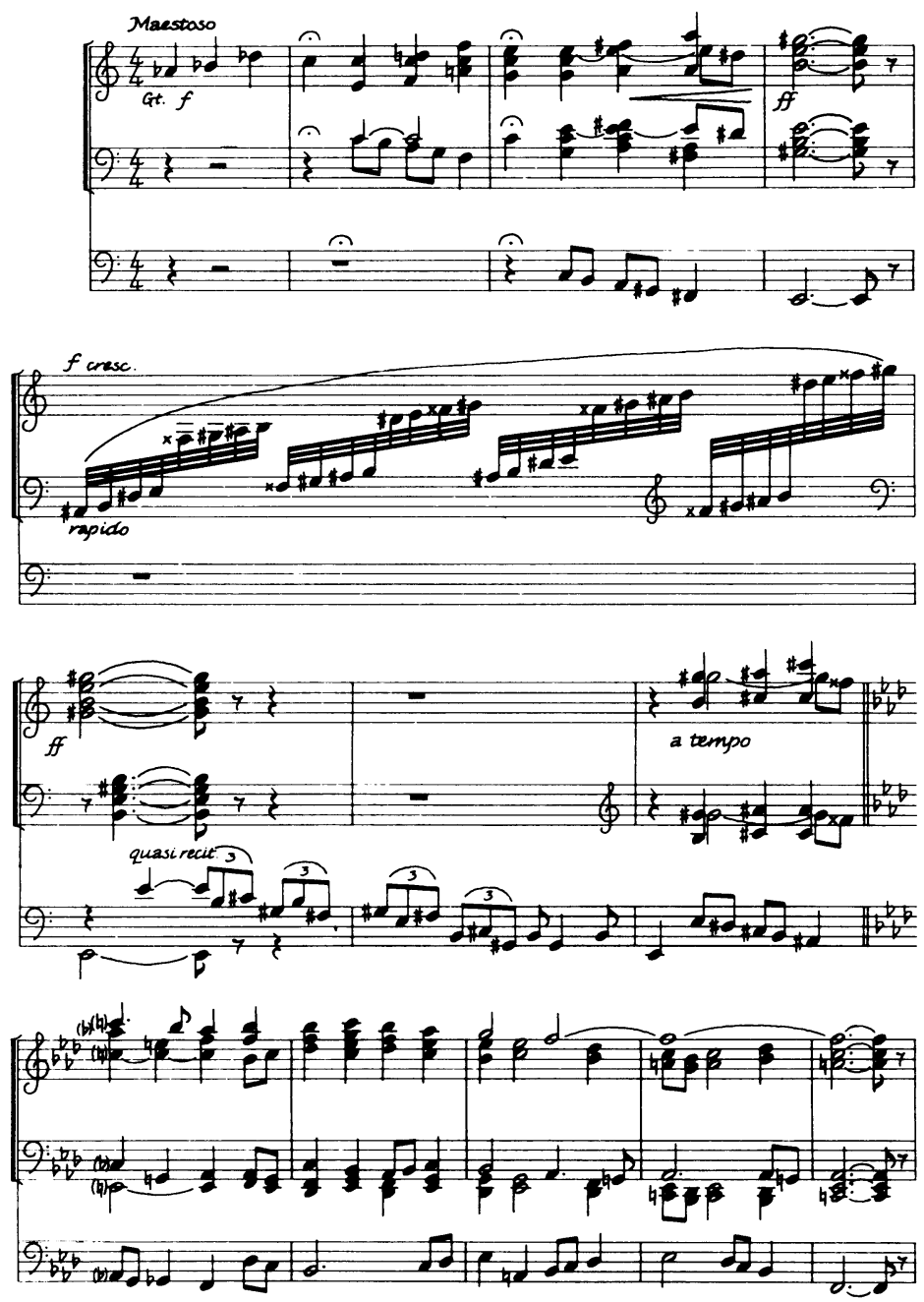

Copyright $\odot 1951$ by Concordia Publishing House. Reprinted by permission.

Example 2. Willan: Chorale Prelude on "Vexilla regis"

(Six Chorale Preludes, Set II, No. 6), mm. 1-12. 
hinting at the tonic $\mathrm{F}$ minor. The motive then rises sequentially by pivot-note modulations through $\mathrm{C}$ major, $\mathrm{E}$ major, and $\mathrm{A}$ flat major before settling in $\mathrm{F}$ minor - a grandiloquent chromatic manner reminiscent perhaps of the opening of Max Reger's Fantasia and Fugue on B-A-C-H, Op. 46 (1900). ${ }^{5}$ The whole passage has such panache that one is left wishing that Willan had written more in this rousing vein.

Among the organ miniatures that do not use a hymn tune as a cantus firmus are several based on hymn-like themes; these have such titles as "Chorale" and "Aria." The "Chorale" preceding the first fugue of the Fugal Trilogy is a four-part setting of a Lutheran-chorale style soprano melody in a Bachian harmonization. In the Andante, Fugue and Chorale, Willan presents a noble chorale setting, fortissimo, with improvisatory interjections constructed from the work's principal motive, senza misura, which separate phrases of the chorale - a highly cohesive and effective use of the cyclic principle (Exx. 3a, 3b, \& 3c):

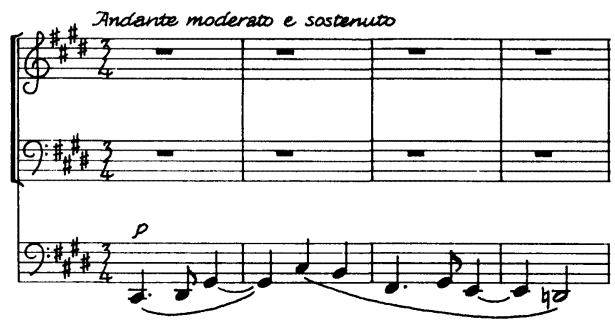

Copyright $\odot 1965$ by C.F. Peters Corporation. Reprinted by permission. Example 3a. Willan: Andante, Fugue and Chorale, mm. 1-4.

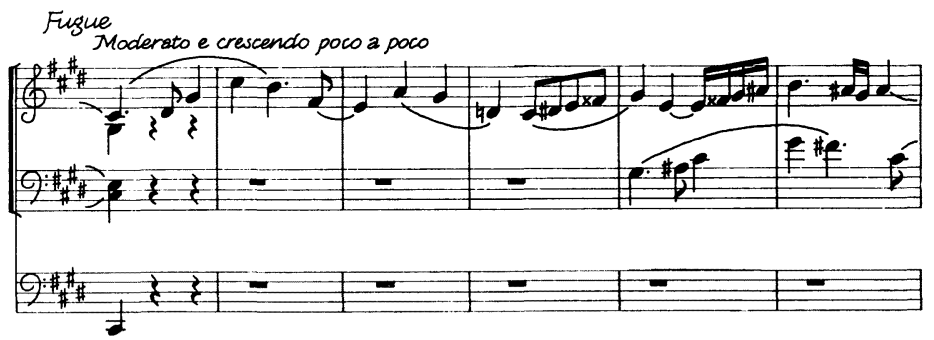

Copyright $\odot 1965$ by C.F. Peters Corporation. Reprinted by permission. Example 3b. Andante, Fugue and Chorale, mm. 42-47. 

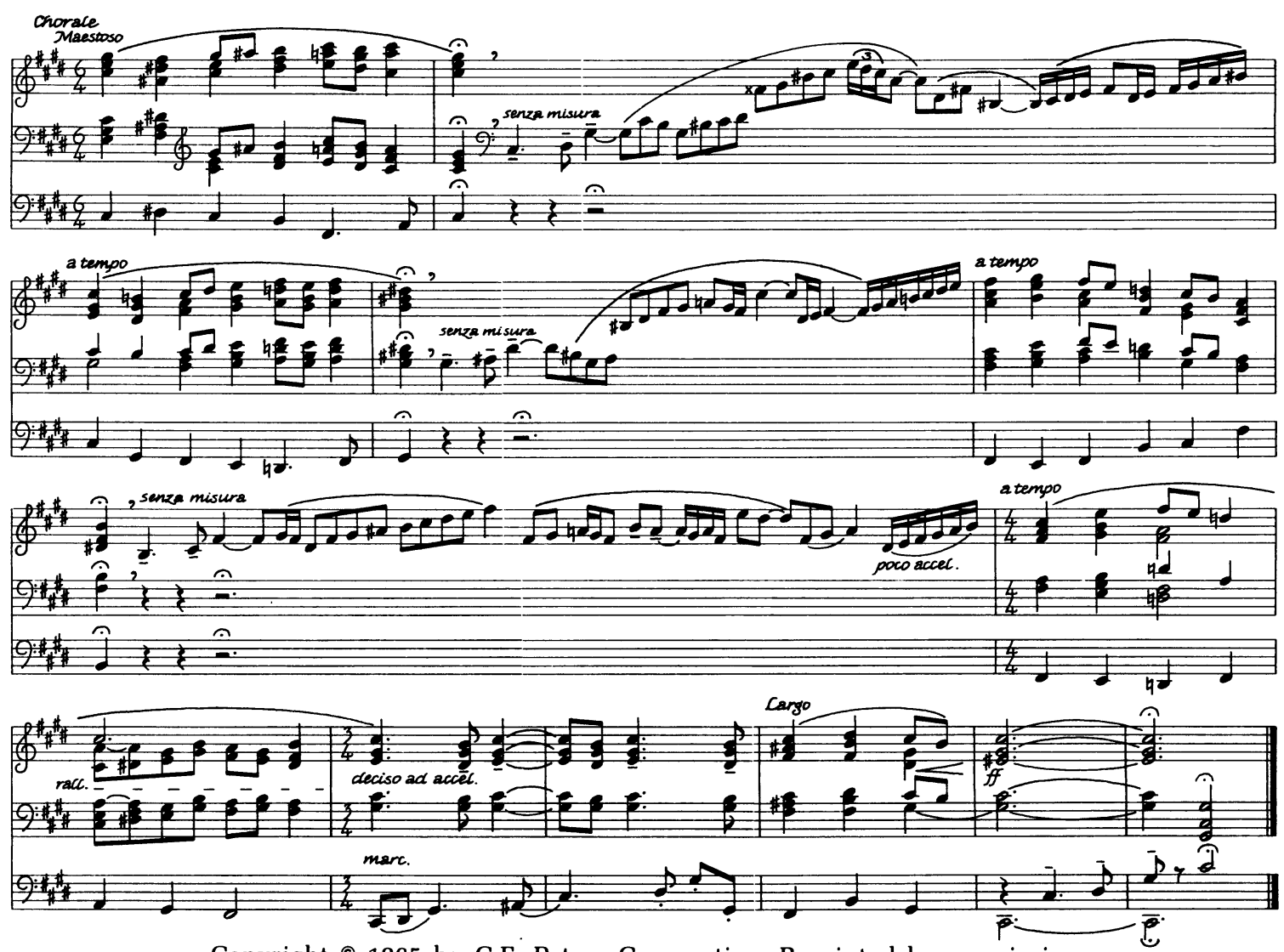

Copyright $\odot 1965$ by C.F. Peters Corporation. Reprinted by permission. Example 3c. "Chorale" from Andante, Fugue and Chorale. 


\section{THE NEWLY-COMPOSED MINIATURES}

In this second category are some thirty-two published works. Twelve are in contrapuntal forms: nine fugues, two sets of variations on ground basses, and one canon. There is the same lack of diversity of approach to fugal writing by comparison with Parry and Stanford as was noted in the hymn-tune works. Only the C sharp minor fugue subject of Willan's Andante, Fugue and Chorale (Ex. 3b), with its hemiola rhythm, is truly imaginative; the remainder are on dull, lackluster themes. But Willan was always a fine contrapuntal craftsman who knew the form and what sounds well on the organ.

While the fugues are traditional in basic style and procedure, they exhibit certain Romantic (as opposed to Baroque) features found in the Mendelssohn, Schumann, Brahms, and Reger organ fugues. First there is the chromaticism within a basically diatonic style. Then there is the tendency to build up poco a poco to a climactic fortissimo conclusion, largemente, with a thickening of the texture, usually from the customary four voices to six or even eight or more. The first and third fugues of the Fugal Trilogy and the fugue in the Andante, Fugue and Chorale receive this kind of treatment, a type of dynamic expansion that suggests the composer was perhaps thinking in terms of the large nineteenth-century orchestra with its capacity for nuance, tone color, and dynamic power.

The chief interest of the Miniature Suite, published in 1910 , is the insight it gives into Willan's early days in Victorian and Edwardian England. The intimate mood of these six character pieces suggests a quite different kind of composer from the swaggering, extroverted Willan of the Epilogue and the Prelude and Fugue in C Minor of 1909. Yet the harmonic language of these early works, whether condensed or expansive, is basically diatonic with chromatic encrustations, influenced by Schumann and Reger rather than Wagner. The six pieces in the Miniature Suite are mainly chordal. The counterpoint shows careful respect for harmonic implications and vertical alignments, without any trace of Willan's later disregard for harmony when molding polyphonic lines.

Written for Gerald Wheeler for the dedication of the organ in St. Matthew's, Ottawa, the Five Pieces, published in 1959, constitute a highwater mark among Willan's miniatures. Each one is an admirably crafted character piece, with a consistency of charm and originality seldom found in Willan's organ music. 
In the opening "Fanfare" the parallel root-position triads on the solo Trumpet stop are effectively set against the thick chords of the Great-Swell tutti choruses in a series of eliding antiphonal phrases. To the rather shrill brassy timbre of the Trumpet line Willan adds piquant major-minor alternations - a simple, yet effective device. In the middle of the movement there are characteristic mediant modulations, in this case rising thirds (A major, $\mathrm{C}$ minor, and $\mathrm{E}$ flat minor):
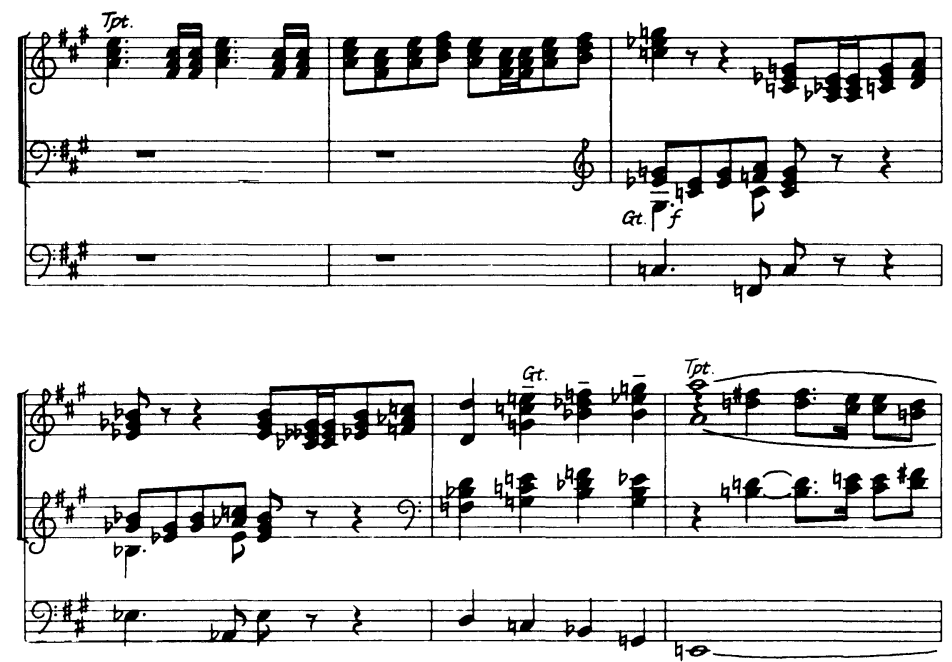

Copyright $\odot 1959$ by Berandol Music Limited. Reprinted by permission.

Example 4. Willan: "Fanfare" (Five Pieces, No. 1), mm. 7-12.

The fourth movement of the Five Pieces, "Scherzo," is a light affair given almost entirely to the manuals. Here, against descending chromatic scales within a fourth in the lowest voice, Willan places a whimsical syncopated two-voice melody that playfully shifts between major and minor. The linear counterpoint results in numerous augmented triads and other dissonant vertical alignments that endow the movement with a bizarre countenance. The various cross-rhythms in each hand, and between the hands, add to the wit of this little gem. 

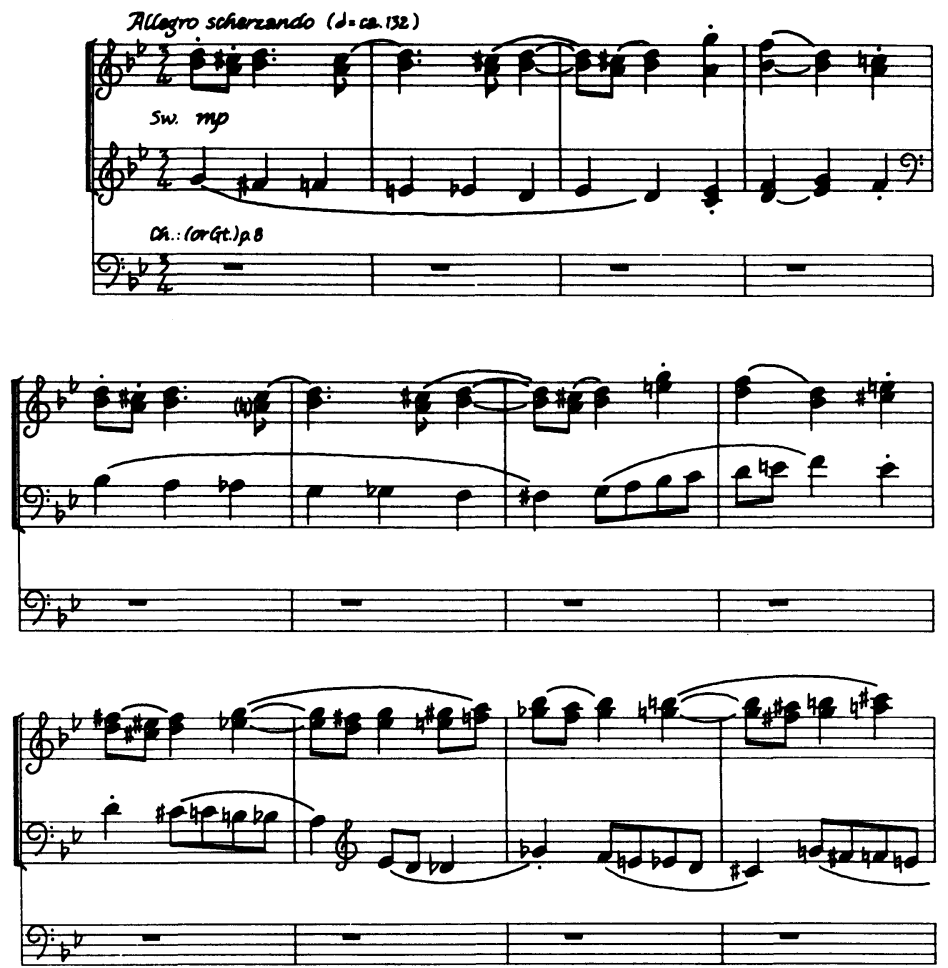

Copyright $\odot 1959$ by Berandol Music Limited. Reprinted by permission. Example 5. Willan: "Scherzo" (Five Pieces, No. 4), mm. 1-12.

The "Finale jubilante" sees a return to the regal mood of the opening "Fanfare," only now there is less of the free improvisatory spirit and a more worked-out impression instead. Once again, Willan seems to have had a feeling for the occasion - for the rejoicing of a congregation at hearing their church's magnificent new organ speaking for the first time - and he has it ring out like a grand peal of bells. 


\section{APPENDIX}

\section{CATALOGUE OF HEALEY WILLAN ORGAN MINIATURES}

Title

Fantasia on "Ad coenam agni" (The Village Organist, Book 45)

Prelude and Fugue in B Minor (Original Compositions, No. 401)

Miniature Suite

Chorale Prelude No. 1 ("Puer nobis nascitur")

Chorale Prelude No. 2 ("Andernach")

Elegy (The Modern Anthology)

Barcarolle

Six Chorale Preludes (Sets I \& II)

Five Preludes on Plainsong Melodies

Chorale Prelude on "Kresmer" (The Parish Organist, Part II)

Chorale Prelude on "St. Thomas" (The Parish Organist, Part III)

Three Pieces

Chorale Prelude on "Adoro Te devote" (Organ Music for the Communion Service)

Chorale Prelude on "Te lucis ante terminum"

Thirty-Six Short Preludes and Postludes on WellKnown Hymn Tunes (3 vols.)

Chorale Preludes on "Easter Hymn" and "Italian Hymn" (The Parish Organist, Part VIII)

Prologue on "Ascension" (Festal Voluntaries: Ascension, Whitsun and Trinity)

Epilogue on "St. Theodulph" (Festal Voluntaries:

Lent, Passiontide and Palm Sunday)

Ten Hymn Preludes (Set I)

Soliloquy (An Easy Album)

Rondino, Elegy and Chaconne

Ten Hymn Preludes (Set II)

Postlude in E Minor (Preludes, Interludes, Postludes, Vol. I)

Ten Hymn Preludes (Set III)

Postlude in D (Album of Praise)

A Fugal Trilogy

Five Pieces

Matins

Evensong

Fugue in $\mathrm{E}$ Minor

Andante, Fugue and Chorale

Chorale Prelude on "Horsley" (The Parish Organist, Part XI)
Published

$1906(\mathrm{~N})$

$1909(\mathrm{~N})$

$1910(\mathrm{~W})^{*}$

1926 (O)

1928 (O)

1947 (G)

1950 (A)†

1950 (C)

1952 (O)

1953 (C)

1953 (C)

1954 (F)

1955 (C)

1955 (O)

1956 (P)

1956 (C)

$1956(\mathrm{~N})$

$1956(\mathrm{~N})$

1956 (P)

1956 (O)

$1957(\mathrm{~N})$

1957 (P)

$1957(\mathrm{H})$

1958 (P)

1958 (O)

1959 (O)

1959 (B)

1961 (P)

1961 (P)

1963 (B) $\ddagger$

1965 (P)

1966 (C) 
Chorale Preludes on "Windsor," "Angel's Story," and "Watermouth" (The Parish Organist, Part XII) 1966 (C) Prelude on "Slane"

*The pieces appeared in 1910 as Nos. 18-23 of original compositions and arrangements; the revised edition of the six pieces, called Miniature Suite, was published by Ascherberg, Hopwood and Crew, London, 1947.

$\dagger$ Begun in 1918, originally as the second movement of an unfinished Suite for Organ, and completed in 1950.

‡Used in the National Film Board of Canada documentary Man of Music (1959). It was published by BMI Canada (1963) as a "Postlude or Offertory" with the Missa Brevis No. 14.
A - Ascherberg, Hopwood \& Crew, London
B - BMI Canada, Toronto
C - Concordia, St. Louis
F - Frederick Harris, Toronto
G - H.W. Gray, New York
$\mathrm{H}$ - Hinrichsen, London
$\mathrm{N}$ - Novello, London
O - Oxford University Press, London
P - C.F. Peters, New York
W - Charles Woodhouse, London 


\section{NOTES}

1. From the Coronation Suite (1953), originally for orchestra, arranged for organ by the composer.

2. The following are treated canonically: "Puer nobis nascitur," "Andernach," "Te lucis ante terminum," "Melcombe" (Ten Hymn Preludes, Set I, No. 6), "St. Flavian" (Ten Hymn Preludes, Set I, No. 5, Variation 1), "Bevan" (Six Chorale Preludes, Set I, No. 5), and "Lobt Gott, ihr Christen" (Six Chorale Preludes, Set II, No. 4).

3. All Saints', Margaret Street, had been the focal point of Anglo-Catholic services in London since the incumbency of the Reverend Frederick Oakeley between 1839 and 1845. Oakeley and his organist at All Saints' from 1839, Richard Redhead, both Oxford graduates and sympathetic to the views of the Oxford Movement (1833-45), published the first Anglican Gregorian psalter, Laudes Diurnae, in 1843. See Rainbow 1970: 3-25.

4. One solution to the problem suggested by Willan himself: if the solo printed on the middle staff is played on the Great manual, the half-notes B flat and $C$ in the right hand in measures 16 and 17 (circled in Ex. 1) may be played by the left hand reaching up to the Swell manual.

5. In the opening page of the Fantasia, Reger also takes his four-note motive through a series of modulations, though his rise by semitonal steps.

\section{REFERENCES}

BRADLEY, I.L.

1977: Twentieth Century Canadian Composers. Vol. 1. Agincourt, Ontario: GLC Publishers Limited.

RAINBOW, B.

1970: The Choral Revival in the Anglican Church (1839-1872). London: Barrie and Jenkins. 